\title{
Science, fake news, and the naked truth
}

\author{
M. Vinchon ${ }^{1,2}$ (D)
}

Received: 5 September 2021 / Accepted: 6 September 2021

(c) The Author(s), under exclusive licence to Springer-Verlag GmbH Germany, part of Springer Nature 2021

Sandro Botticelli painted Apelle's Calumny (La Calunnia di Apelle) around 1495, as a tribute to the half-mythic painter of antiquity Apelles (fourth century BC) [1]. Nothing survives from Apelle's painted works, except perhaps, as hypothesized by Moreno [2], the mosaic "Alexander's battle" from the House of the Faun in Pompei, now displayed in the antiquities museum in Naples, which might have been created from one of his paintings. In spite of this, Apelle's memory survived through the writings of classic authors as the ideal of antique painting, and he was much revered during the renaissance period. Botticelli recreated Apelle's work after the depiction written by Lucian of Samosata during the second century AD. This panel, to be admired in the Uffizi Gallery in Florence, is an allegory of the evil influences at play during a legal procedure, featuring an innocent victim, being dragged to the court by Calumny, the latter carrying a torch, and king Midas, in his regal privilege of justice, under the influence of evil characters spinning fake news. On the left, the naked Truth, points at the heaven from which enlightenment will finally be revealed.

The naked truth is also illustrated by the sculpture "nature unveiling before science" (Fig. 1 and Cover), an art-deco sculpture commissioned by the Conservatoire des Arts et Métiers, a temple of engineering sciences, and executed in 1899 by Louis-Ernest Barrias. It can now be seen in its polychrome glory in the Musée d'Orsay in Paris, while a simpler marble version stands in the grand staircase of the Faculté de Médecine in Paris.

M. Vinchon

matthieu.vinchon@chru-lille.fr

1 Department of Pediatric Neurosurgery, Lille University Hospital, Lille, France

2 Service de Neurochirurgie Pédiatrique, CHRU de Lille, 59037 Lille Cedex, France
Science, nature, and truth entertain a tight relationship symbolized by beauty and nakedness. The dark powers of ignorance and deceit were unleashed during the series of crises which, with the perspective of history, constitute the Renaissance; they are rising again during our era of climatic turmoil, conflicts, and epidemics. Science must wage an unending war against fantasies, fallacies, falsities, and fake news. The scientists' values of objectivity, humility, absence of prejudice, patient analysis of facts, however challenged in the press or in courts, must be held proudly and defended.

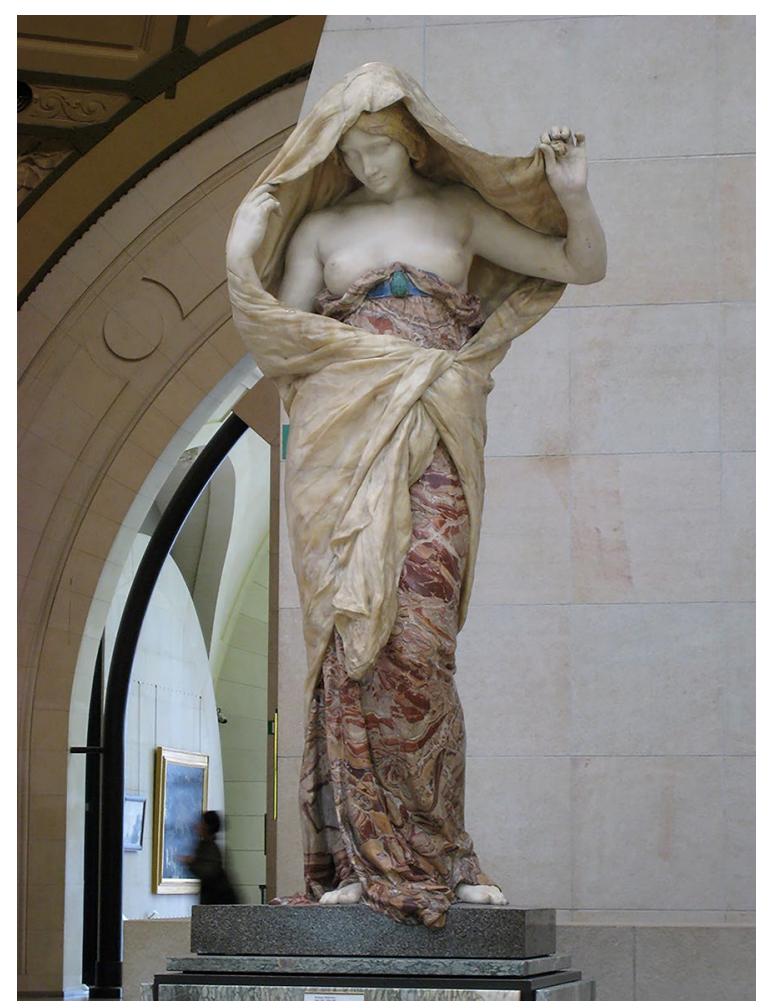

Fig. 1 and Cover Nature unveiling before science, polychrome sculpture by Barrias, Musée d'Orsay, Paris, France 
Supplementary information The online version contains supplementary material available at https://doi.org/10.1007/s00381-021-05362-x.

Funding We the authors, declare no funding.

Data and materials availability Data and material are stored and will be made available upon request.

\section{Declarations}

Consent for publication We the authors give our consent for publication and will transfer copyright upon acceptance.
Conflict of interest/Competing interest No conflicts of interest and no competing interests.

\section{References}

1. Calumny of Apelles (Botticelli). https://en.wikipedia.org/wiki/ Calumny_of_Apelles_(Botticelli)

2. Moreno P (2000) Apelle. La battaglia di Alessandro, Skira

Publisher's Note Springer Nature remains neutral with regard to jurisdictional claims in published maps and institutional affiliations. 